\title{
MAKNA CANTIK DALAM IKLAN TELEVISI PRODUK CITRA VERSI “PEARLY WHITE UV ESSENCE CREAM"
}

\author{
Ayu Mispa Putri' ${ }^{1}$, Arie Prasetio ${ }^{2}$ \\ Universitas Telkom \\ Email: ayu.mispa@gmail.com ${ }^{1}$, arijatock@gmail.com ${ }^{2}$
}

\begin{abstract}
ABSTRAK
Konsep cantik dalam iklan memberi makna dari alur cerita yang ditayangkan. Seperti iklan Televisi produk Citra, setiap adegan pada iklan "Citra Pearly White UV Essence" mengandung elemen yang memiliki makna, mulai dari bunyi, gerakan, kata-kata, dan visualnya. Iklan kecantikan biasanya menampilkan seorang wanita yang memiliki tubuh indah, kaki panjang, kulit putih mulus dan indah. Penelitian ini bertujuan untuk mengetahui simbol atau tanda dan makna kecantikan dalam produk kecantikan Citra versi "Pearly White UV Essence Cream" di televisi. Penelitian ini menggunakan metode penelitian kualitatif dengan paradigma konstruktivisme dan data dianalisis dengan menggunakan model Semiotik Charles Sanders Pierce yang menghasilkan data seperti kecantikan yang dimiliki oleh seorang wanita berkulit putih, yang ditampilkan pada setiap tanda pada adegan yang dipotong, seperti tubuh, rambut, wajah hingga atribut yang digunakan untuk menggambarkan bagaimana iklan Citra menggambarkan kecantikan yang dimiliki oleh wanita berkulit putih. Arti kecantikan dalam iklan Citra versi "Pearly White UV Essence" adalah kecantikan modern, kecantikan religius dan kecantikan yang sehat.
\end{abstract}

Kata kunci: semiotika, iklan, makna kecantikan

\section{PENDAHULUAN}

Media massa sebagai media penyebaran informasi penting bagi masyarakat, penyebaran informasi secara terus menerus membuat masyarakat tidak dapat lepas dari media massa, salah satunya yaitu media televisi. Televisi dinilai sebagai media massa elektronik yang diasumsikan dapat mempengaruhi khalayaknya melalui program tayangannya. Donald k. Robert mengungkapkan, asa yang beranggapan bahwa "efek hanyalah perubahan perilaku manusia setelah diterpa pesan media". Karena fokusnya pesan, maka efek harus berkaitan dengan psan yang disampaikan media massa. Dalam hal ini televisi bermanfaat sebagai pembentuk sikap, perilaku, dan sekaigus pola pikir (Ardianto, 2009:51). Dari sekian banyak tayangan televisi, iklan adalah salah satunya. Iklan merupakan ujung tombak kekuatan industri budaya 
untuk memperluas pangsa pasar dan sebagai media untuk mendapatkan keuntungan dalam dunia persaingan usaha yang semakin komptitif. Karena iklan bersifat dapat menjangkau sasaran yang lebih spesifik, sasarannya dapat dipilih, dapat dibedakan berdasarkan segmentasi produk yang akan dijangkau. Targetnya, salah satunya yaitu perempuan melalui iklan produk kecantikan.

Suatu studi terhadap 4.294 iklan televisi di Inggris menunjukan bahwa pernyataan mengenai kemenarikan fisik perempuan paling umum ditampilkan melalui profil perempuan dan disuarakan oleh laki-laki menurut Downs \& Harrison,1985 dalam (Melliana, 2006:60). Pesan bahwa perempuan harus bertubuh menarik dan cantik fisiknya agar dapat diterima, disuarakan dengan keras dan jelas dalam jaringan iklan televisi. Fitur ideal tersebut mendorong para perempuan untuk mengharapkan tubuh yang indah dan cantik seperti apa yang telah ditampilkan dalam iklan tersebut. Periklanan sering kali menampilkan perempuan dengan figur yang memiliki tubuh indah, kaki panjang, kulit putih mulus dan cantik. Setiap perempuan mengartikan kata cantik berbeda-beda, ada yang mengartikan cantik dilihat dari fisik, cantik karena pintar, cantik karena hatinya dan yang lain, namun menurut survey global yang dilakukan oleh Dove menampilkan hasil bahwa $98 \%$ perempuan didunia tidak memilih kata cantik untuk menggambarkan diri sendiri, hanya $45 \%$ perempuan didunia yang menggambarkan dirinya cantik, survey yang dilakukan menunjukan bahwa rata-rata perempuan masih menganggap bahwa cantik dilihat dari fisik terutama paras (Sumber:https://www.dove.com/us/e $\underline{\text { n/stories/about-dove/our- }}$

research.html). Hal ini dikarenakan perempuan rata-rata masih menganggap bahwa cantik diukur dari fisiknya saja, dari survey yang dilakukan oleh ZAP beauty rata-rata perempuan Indonesia menginginkan produk kecantikan yang dapat mencerahkan kulit dengan persentase $59,5 \%$ untuk perempuan genersi $X$ dan $60,5 \%$ untuk perempuan generasi milenial (sumber:http://zapclinic.com/zapbea utyindex). Di Indonesia juga 
perempuan masih mengukur kadar cantik melalui kulit yang putih cerah.

Produk kecantikan seringkali menjanjikan keunggulan produknya mulai dari mencerahkan kulit, memutihkan kulit, sampai dengan menghilangkan dan menyamarkan noda jerawat, salah satunya produk kecantikan yaitu Citra. Konsep iklan kecantikan memberi makna tersendiri dari jalan cerita yang ditayangkan. Seperti halnya iklan televisi produk Citra, setiap adegan yang tedapat dalam iklan Citra Pearly White UV Essence mengandung unsur-unsur yang memiliki makna, mulai dari suara, gerakan, kata dan visual. Dalam Iklan Citra tersebut menggambarkan seorang wanita yang memiliki kulit cerah bersinar, warna kulitnya-pun tidak masuk dalam alat pengukur warna kulit. Iklan Citra ini berusaha menggambarkan standar kecantikan yang baru dan dalam iklan Citra tersebut juga menekankan dengan monolog yaitu "inilah standar yang baru". Pada dasarnya iklan kecantikan menjadi suatu barometer tersendiri bagi perempuan. Melalui iklan kecantikan munculah standar standar cantik yang kemudian selalu diikuti oleh perempuan.
Setiap adegan yang tedapat dalam iklan Citra Pearly White $U V$ Essence Cream mengandung unsurunsur yang memiliki makna, mulai dari suara, gerakan, kata dan visual. Unsur-unsur tersebut yang kemudian oleh penulis akan teliti menggunakan analisis semiotika Charles Sanders Peirce. Aspek-aspek yang akan diteliti berupa konten kata, gambar dan gerakan yang terdapat dalam iklan televisi Citra versi "Pearly White UV Essence Cream". Aspek tersebut akan dianalisis dengan menggunakan analisis semiotika Charles Sander Pierce dengan cara memberi perhatian pada pemaknaan sesuai dengan segitiga makna yaitu, sign, interpretant, dan object.

Iklan adalah segala bentuk pesan tentang suatu produk disampaikan melalui suatu media, dibiayai oleh pemrakarsa yang dikenal, serta ditujukan kepada sebagian atau seluruh masyarakat. Menurut Keegan et.al, seperti yang dikutip oleh Mahmud Machfoedz dalam bukunya, Komunikasi Pemasaran Modern (Machfoedz, 2010:139), iklan adalah segala bentuk penyajian informasi dan promosi secara tidak langsung yang dilakukan 
oleh sponsor untuk menawarkan ide, barang, atau jasa. Iklan secara sederhana adalah instrumen atau sarana untuk mempromosikan dan memasarkan barang dalam masyarakat industrial.

Iklan televisi merupakan iklan yang ditayangkan pada media massa yaitu televisi berupa visual, audio, dan gerak. Iklan televisi dibuat dengan menonjolkan visualisai objek dan visualisasi audio, objek-objek yang divisualisasikan lebih banyak ketimbang simbol-simbol verbal. Menurut Bungin (2008:111), iklan televisi adalah salah satu dari iklan lini atas (above-the-line).

Iklan merupakan sebuah potret realitas yang ada didalam masyarakat yang dikonstruksikan oleh media televisi. Menurut Bungin (2008:2), dari realitas kekuatan media mengkonstruksi realitas sosial, dimana melalui kekuatan itu media memindahkan realitas sosial kedalam pesan media dengan atau setelah dirubah citranya, kemudian media memindahkannya melalui replika citra kedalam realitas sosial yang baru dimasyarakat, seakan realitas itu sedang hidup dimasyarakat. Realitas sosial dikonstruksi melalui proses eksternalisasi, obyektivasi dan internalisasi. Realitas yang dilebihlebihkan atau yang disebut dengan hiperrealitas ini merupakan efek dari proses simulasi. Menurut Piliang (2016:132), simulasi sebagai model produksi penampakan dalam masyarakat konsumer, menurut Baudrillard, tidak lagi berkaitan dengan duplikasi ada (Being) atau substansi dari sesuatu yang diduplikasi, melainkan, penciptaan melalui model-model sesuatu yang nyata yang tanpa asal-usul atau realitas, hyperalitas. Dalam hal ini iklan dibuat dengan melihat realitas yang ada dimasyarakat yang kemudian dikemas kembali menjadi realitas baru yang seolah-olah realitas itu sedang hidup dimasyarakat, dapat dikatakan bahwa realitas yang dibuat oleh iklan merupakan realitas yang dilebih-lebihkan atau hiperrealitas. Seperti halnya iklan kecantikan produk Citra, dimana iklan tersebut digambarkan dengan model yang memiliki kulit bersih dan cerah merona setelah memakai produk dari Citra, dalam hal ini media telah mengkonstruksi iklan Citra, bahwa dengan hanya menggunakan produk 
Citra maka para perempuan akan mendapatkan kulit yang bersih, cerah merona seperti model dalam iklan tersebut.

Blumer (1969) menjelaskan bahwa terdapat tiga cara untuk menjelaskan asal sebuah makna. Satu pendekatan mengatakan bahwa makna adalah sesuatu yang bersifat intrinsik dari suatu benda. Pendekatan kedua terhadap asal-usul makna melihat makna itu "dibawa kepada benda oleh seseorang bagi siapa benda itu bermakna”. Makna adalah "produk sosial" atau "ciptaan yang dibentuk dalam dan melalui pendefinisian aktivitas manusia ketika mereka berinteraksi" (West\&Turner, 2008:100). Brown dalam (Mulyana,2000:256), mendefinisikan makna sebagai kecenderungan (disposisi) total untuk menggunakan atau bereaksi terhadap suatu bentuk bahasa. Terdapat banyak komponen dalam makna yang dibangkitkan sauatu kata atau kalimat. Dengan kata-kata Brown, "seseorang mungkin mengahbiskan tahun-tahunnya yang produktif untuk menguraikan makna suatu kalimat tunggal dan akhirnya tidak menyelesaikan tugas itu".
Kata cantik sudah melekat pada diri perempuan, dimanapun perempuan berada dan diusia berapapun perempuan akan selalu dituntut untuk tampil cantik. Tuntutan tampil cantik inilah yang menjadi adanya standar kecantikan di dalam masyarakat. Kecantikan merupakan bagian dari sistem budaya yang direpresentasikan melalui simbol. Simbol dalam tubuh adalah sesuatu yang disampaikan sekaligus disembunyikan, maka dari itu tubuh manusia yang awalnya menjadi tubuh alami, kemudian dibentuk menjadi tubuh sosial atau fakta sosial. Tubuh perempuan sendiri sudah menerima konstruksi-konstruksi sosial bentukan budaya, tubuh perempuan dikonstruksi melalui kecantikan dengan memberikan standarisasi terhadap bibir, wajah, tubuh, rambut hingga warna kulit. Perempuan harus menerima konstruksi dan standarisasi yang sudah ditetapkan ini sebagai hal yang alamiah. Menurut Abdullah (dalam Nurhayati, 2017) masingmasing budaya memiliki kekhasan (tipikal) kecantikan yang ditunjukan melalui ciri-ciri fisik dan nonfisik, yang bersifat komulatif, mencakup ukuran-ukuran tubuh tertentu yang 
ideal, misalnya kulit putih, rambut hitam, badan kurus, pinggang ramping, serta kepribadian (inner beauty) yang baik. Ciri-ciri atau indikator semacam ini pada akhirnya melahirkan tipologi, konsep kecantikan perempuan, dari waktu ke waktu selalu mengalami perubuhan, mulai dari yang bersifat seksual semata, sampai ke politis sehingga disebut dengan istilah dialektika konstruksi kecantikan.

\section{METODE PENELITIAN}

Pada penelitian ini menggunakan paradigma konstruktivisme dengan menggunkan metode kualitaif dan analisis semiotika Charles Sanders Peirce. Objek dalam penelitian ini yaitu makna dalam iklan televisi produk Citra Pearly White UV Essence Cream. Teknik pengumpulan data berupa data primer dan sekunder. Data primer adalah mengumpulkan data bersal dari sumbernya yaitu pada video iklan produk Citra. Data sekunder adalah sumber data berdasarkan kajian literature. Teknik analisis data yaitu berasal dari video dengan melakukan pengolahan gambar pada video iklan dan memilah potongan gambar berdasarkan tanda yang akan diamati lalu menganalisis potongan gambar tersebut sesuai dengan teori triangle meaning Charles Sanders Peirce. Teknik keabsahan data yaitu ketekunan/keajegan pengamatan, triangulasi teori dan triangulasi sumber.

\section{HASIL DAN PEMBAHASAN}

Video iklan Citra ini menggambarkan 2 orang perempuan yang memiliki kulit kusam yang hendak mengukur warna kulitnya menggunakan alat pengukur warna kulit, lalu datang seorang peremuan (Citra Kirana) yang memiliki kulit bening, cerah bercahaya. Dalam video tersebut menggambarkan secara terang-terangan mengenai standar kecantikan. Iklan Citra dengan gamblang menetapkan bahwa model dalam iklan tersebut merupakan standar kecantikan, model dengan kulit putih bening bercahaya dan mulus. 


\begin{tabular}{ccc}
\hline Nomor & Gambar \\
\hline 1 & \\
& & \\
& & \\
& &
\end{tabular}

\section{Deskripsi}

Terliha seorang perempuan berkulit gelap dengan ekspresi wajah tersenyum sedang memegang alat pengukur warna kulit dan cermin. 1 memperlihatkan bahwa tingkat putih pada kulit sangatlah penting, hal ini menunjukkan bahwa perempuan yang cantik dilihat dari tingkat warna kulitnya.

\section{Deskripsi}

Seorang perempuan yang sedang berjalan menghampiri dua temannya yang sedang duduk dengan berlatarkan pantai , perempuan tersebut memiliki kulit putih yang cerah dengan mengenakan mini dress dengan bahu terbuka berwarna merah muda (Pink). Model dalam potongan gambar diatas digambarkan dengan mengenakan mini dress pink yang memperlihatkan bahu dan bentuk tubuhnya, disini perempuan cantik digambarkan dengan memiliki bentuk tubuh yang bagus, bahu yang putih mulus dan indah, serta memiliki rambut hitam legam dan lurus.

\begin{tabular}{cccc}
\hline Nomor & Gambar \\
\hline 3 & & \\
\hline
\end{tabular}

\section{Deskripsi}

Meperlihatkan perempuan berbaju merah muda menolak saat temannya ingin mengukur warna kulitnya. menunjukkan bahwa kulit putih cerah yang dimiliki oleh perempuan berbaju merah muda tidak akan ada ukurannya. Ini memperlihatkan kepercayaan diri dengan tidak mengkhawatirkan seberapa tingkat putih kulit yang dimiliki. Hal ini juga menunjukkan bahwa kecantikan merupakan mereka yang memiliki kulit putih 


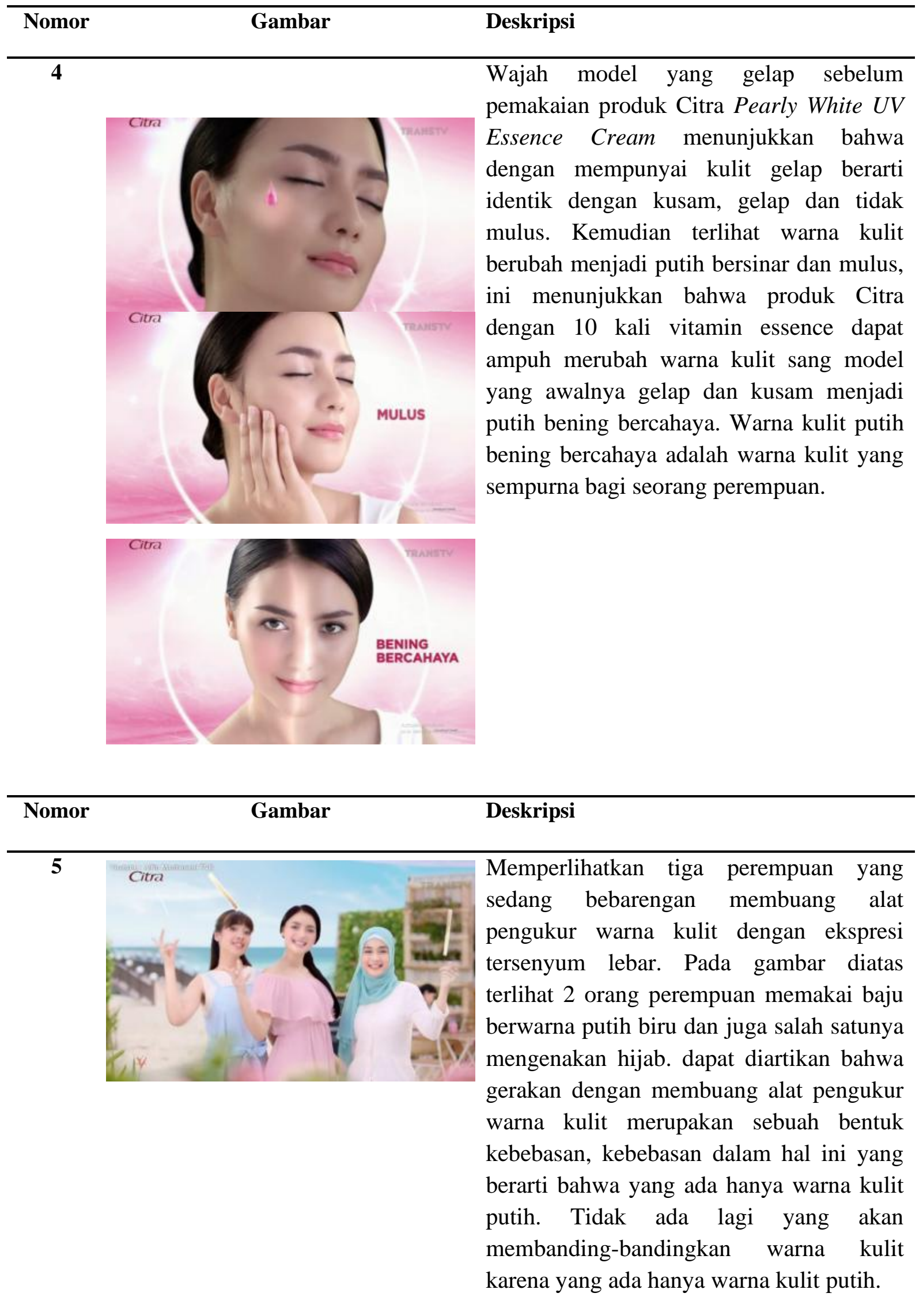




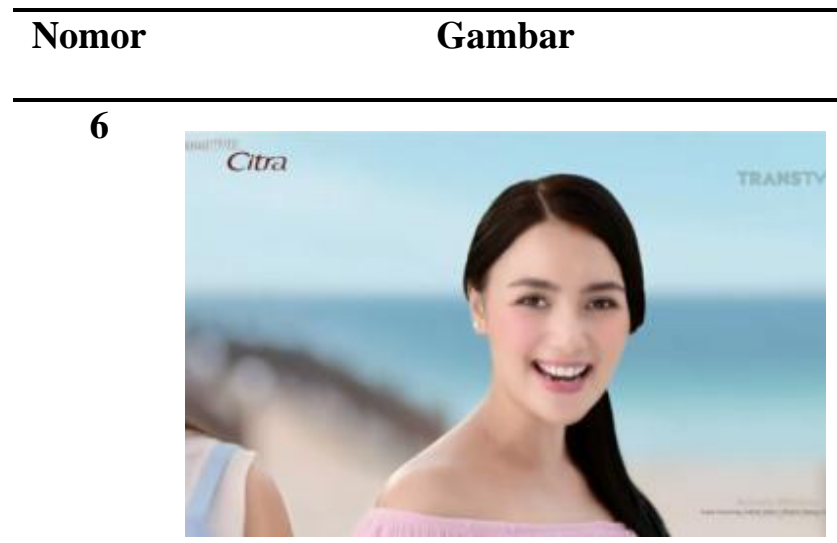

\section{Deskripsi}

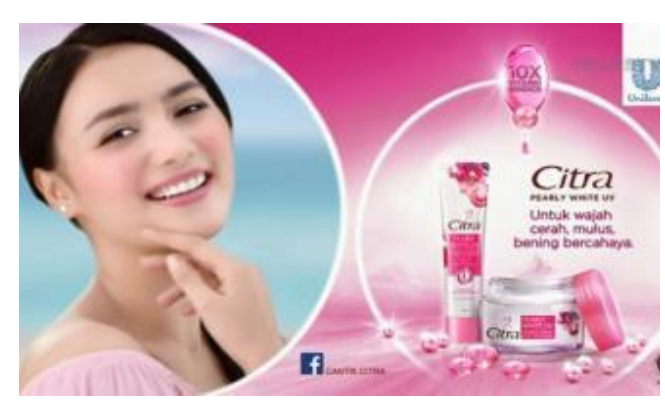

Memperlihatkan wajah model utama pada Scene ini terlihat detail dan ekspresi model yang senang sembari memegang kulit dagunya. terlihat sang model yaitu Citra Kirana yang sedang tersenyum sambil tangannya memegang dagu yang menandakan bahwa sang model sangat bangga dan bahagia dengan memiliki kulit yang putih.

Dalam penyebaran pemikiran bahwa wanita dengan kulit putih merupakan standar kecantikan tidaklah luput dari peran media massa didalamnya. Media massa terutama iklan berperan besar dalam menyebarkan suatu ideologi dalam masyarakat. Dalam iklan Citra terlihat sangat jelas bahwa pembuat iklan ingin menegaskan secara terang-terangan bahwa standar cantik merupakan perempuan dengan kulit putih bening bercahaya dan mulus, ini terlihat pada setiap scene. Pada gambar 1 terlihat perempuan dengan alat pengukur warna kulit dengan narasi "cek cerah yuk" yang berarti bahwa perempuan sangat ingin memiliki kulit yang putih, kekhawatiran akan warna kulit yang dimiliki membuat perempuan suka membandingkan dengan mengecek seberapa tingkat cerah warna kulit yang dimiliki.

\section{Pandangan bahwa cantik} merupakan dengan berkulit putih tidak hanya datang pada zaman kolonialisme Barat, namun sejak zaman Ramayanapun standar kecantikan sudah muncul pada abad ke-9 dan awal abad ke 10 sebelum kolonialisasi Eropa. Seperti epos India Ramayana yang diadaptasi di Jawa. Dalam kisah Ramayana 
mengandung hierarki warna sebagaimana pemilihan antara terang dan kulit terang sebagai hal yang diinginkan dan gelap dan kulit gelap sebagai yang tak diinginkan (Saraswati, 2017:16). Artinya bahwa warna kulit putih merupakan warna kulit yang perempuan inginkan sedangkan warna hitam atau gelap merupakan warna kulit yang tak dinginkan.

Dalam gambar nomer 2, model utama (Citra Kirana) digambarkan dengan perempuan berkulit putih bercahaya, dengan lekukan tubuh yang ramping mengenakan mini dress berwarna pink, rambut panjang diikat kesamping untuk memperlihatkan bahu yang indah, berjalan dengan anggun. Dalam hal ini cantik dalam iklan Citra digambarkan dengan perempuan berkulit putih merupakan perempuan yang identik dengan sifat feminim, lemah lembut serta anggun. Perempuan dengan kulit putih juga identik dengan perempuan yang memiliki tubuh yang indah sebagaimana digambarkan dalam gambar ke 2. Iklan Citra berusaha menggambarkan cantik merupakan perempuan yang sempurna yaitu perempuan dengan kulit berwarna putih, wajah tanpa cela, tubuh proporsional dan juga mempunyai rambut hitam, lurus dan panjang.

\section{Dalam iklan Citra kecantikan} dapat diklasifikasikan seperti dalam penelitian Nurhayati (2017) yaitu,

a. Dalam iklan Citra berusaha menggambarkan cantik merupakan perempuan yang sempurna yaitu perempuan dengan kulit berwarna putih, wajah tanpa cela, tubuh proporsional dan juga mempunyai rambut hitam, lurus dan panjang. Kecantikan tersebut merupakan kecantikan perempuan modern. Dimana dalam iklan Citra kecantikan digambarkan dengan kecantikan perempuan yang sempurna dengan memperlihatkan sebagian tubuhnya yaitu bahu yang nampak mulus, memiliki betis yang ramping dan indah, jemari tangan yang dirawat dan bersih dan juga memiliki rambut hitam lurus dan panjang.

b. Pada scene 5 juga memperlihatkan dua orang memakai baju berwarna putih 
dan biru yang bermakna

kepercayaan,

keamanan,

kebersihan, dan steril. Hal ini

berarti bahwa produk Citra merupakan produk yang terpercaya keamanan, kebersihan dan kesterilannya. Aman juga digunakan untuk wanita yang berhijab. Seperti yang diketahui bahwa Indonesia merupakan negara yang mayoritas penduduknya Muslim. Produk dengan berlabelkan halal dan kandungan dalam produk sangatlah penting bagi kaum Muslim. Pada dasarnya banyak produk kosmetik yang menggunakan bahan seperti Babi sebagai salah satu kandungan dalam produknya. Produk pemutih kulit juga kerap kali mengandung bahan yang berbahaya seperti merkuri yang dapat membahayakan tubuh. Dengan menggunakan salah satu model yang memakai hijab menandakan bahwa produk Citra memiliki kandungan bahan yang aman untuk digunakan dan juga halal digunakan untuk perempuan dan perempuan Muslim. Dalam penelitian yang dilakukan Nurhayati (2017) juga memperlihatkan bahwa warna putih menunjukkan kesan murni dan sederhana, kecantikan tersebut termasuk kedalam kecantikan religius.

c. Iklan Citra juga menggambarkan kecantikan sehat, dimana dalam iklan Citra memperlihatkan kandungan yaitu 10 kali vitamin essence yang terbuat dari pearl (mutiara). Mutiara merupakan bahan alami yang dapat mencerahkan wajah. Penggunaan atribut berwarna putih dan biru juga melambangkan kepercayaan, keamanan, kebersihan dan steril yang mendukung bahwa poduk Citra merupakan produk yang terjamin keamanannya untuk dipergunakan.

Pangsa pasar iklan dan produk Citra merupakan masyarakat Indonesia, yang dapat diketahui bahwa mayoritas penduduk Indonesia beragama Islam. Model dengan menggunakan hijab dimaksudkan untuk perempuan-perempuan Muslim di Indonesia namun dalam iklan Citra lebih dominan kepada perempuan yang tidak menggunakan hijab, 
kecantikan dalam iklan Citra lebih berfokus kepada model yang memiliki kulit putih, tubuh proporsional dan juga berambut hitam panjang, selanjutnya model kedua yang memiliki rambut pendek dan berponi digambarkan memiliki kulit yang gelap dan juga memiliki tinggi badan yang lebih pendek dari model utama, seolah iklan Citra menggambarkan perempuan dengan kulit gelap merupakan perempuan yang memiliki tubuh yang pendek, sedangkan model dengan hijab juga digambarkan memiliki tubuh yang pendek. Citra menyampaikan bahwa sebuah kecantikan sempurna melalui model utama (Citra Kirana) yaitu memiliki tubuh yang proporsional dan juga putih. meskipun menampilkan model dengan hijab dalam iklan Citra namun porsi penayangannya lebih sedikit dibandingkan dengan dua model lainya. Ini seolah iklan Citra meminoritaskan perempuan berhijab dan juga perempuan yang memiliki kulit gelap.

Tentu adegan membuang alat pengukur warna kulit setelah mendapatkan warna kulit putih karena penggunaan produk dari Citra memiliki makna yang mendalam. Adegan membuang menyiratkan sebuah kebebasan, bahwa dengan memiliki warna kulit putih merupakan sebuah kebebasan, tidak ada lagi perbandingan antara warna kulit, yang ada hanya warna kulit putih. hal tersebut menunjukkan bahwa seberapa kuat warna kulit mempengaruhi status seseorang.

\section{KESIMPULAN}

$\begin{array}{ccc}\text { Pada } & \text { iklan } & \text { Citra } \\ \text { menggambarkan } & \text { kecantikan } & \text { yang } \\ \text { dimiliki oleh } & \text { perempuan } & \text { yang } \\ \text { memiliki kulit putih. Iklan } & \text { Citra }\end{array}$
menerapkan standar cantik secara terang-terangan dengan menyebutkan "standar cerah yang baru". Seorang perempuan dianggap cantik berdasarkan standar tertentu, maka perempuan tersebut adalah perempuan berkulit putih ini terlihat dari tanda-tanda yang terdapat dalam setiap potongan gambar seperti tubuh yang proporsional, rambut hitam lurus, hidung macung hingga atribut yang dipergunakan menggambarkan bagaimana iklan Citra menggambarkan perempuan cantik dengan berkulit putih. Dalam iklan Citra juga kecantikan perempuan 
berkulit putih merupakan suatu kebebasan, dimana penggambaran tanda melalui alat pengukur warna, dengan berkulit putih terbebas dari pandangan buruk dan pandangan akan warna kulit

Makna kecantikan dalam iklan Citra versi "Citra Pearly White UV Essence" yaitu kecantikan modern, kecantikan religius dan juga kecantikan sehat. Dimana perempuan digambarkan dengan kecantikan yang sempurna dengan memiliki kulit yang putih, memiliki tubuh yang proporsional, memiliki rambut yang hitam lurus, dan berhidung mancung. Sedangkan penggunaan atribut keagamaan seperti hijab menggambarkan kecantikan religius yang didukung dengan penggunaan warna putih. bahan-bahan yang terkandung dalam iklan Citra merupakan bahan yang aman dan juga bahan yang alami. Penggunaan atribut dengan warna putih dan biru menandakan kepercayaan, keamanan, kebersihan, dan steril yang menandakan kecantikan sehat.

\section{DAFTAR PUSTAKA}

Ardianto, Elvinaro dkk. 2009.

Komunikasi Massa Suatu

Pengantar Edisi Revisi.

Bandung: Simbiosa Rekatama Media.

Bungin, Burhan. 2008. Konstruksi Sosial Media Massa. Jakarta: Kecana.

Dameira, Anne. 2007. Color Basic (Panduan Dasar Warna Untuk Desainer \& Industri Grafika. Jakarta: Link Mtach Grafik.

Kaspan, Kartini.S. 2016. Beauty morphosis: Ketika Cantik Fisik Saja Tidaklah Cukup. Jakarta: Gramedia Pustaka Utama

Machfoedz, Mahmud. (2010). Komunikasi Pemasaran Modern. Yogyakarta: Cakra Ilmu.

Melliana, S. Annastasia. 2006. Menjelajah Tubuh Perempuan dan Mitos Kecantikan. Yogyakarta: LkiS.

Mulyana, Deddy. 2000. Ilmu Komunikasi, Suatu 
Pengantar. Bandung: PT

Remaja.

Piliang, Yasraf Amir. (2016).

Hipersemiotika Tafsir

Cultural Studies Atas Matinya

Makna. Yogyakarta: Jalasutra

Saraswati, L.Ayu. 2017. Putih:

Warna Kulit, Ras dan

Kecantikan di Indonesia

Transnasional. Serpong:

Marjin Kiri.

West, Richard dan Lynn H. Turner. 2008. Pengantar Teori

Komunikasi: Analisis dan

Aplikasi. Jakarta: Salemba

Humanika

\section{Disertasi:}

Nurhayati, Iis Kurnia. (2017).

Penanda Metawacana dan Metafungsi Dalam Iklan Produk Kosmetika Indonesia Berbahasa Inggris: Analisis Multimodal. Bandung

Internet:

Dove. 2018. Dove Research. Diakses pada (Rabu, 12 Desember 2018 , 10:55) https://www.dove.com/us/en/ stories/about-dove/ourresearch.html

ZapClinic. 2018. Zap Beauty Index. Diakses pada (Minggu, 6 Januari 2019， 19:36) http://zapclinic.com/zapbeaut yindex 